KENESEI Zsófia - JANECSKÓ Eszter

\title{
ÖNKISZOLGÁLÓ TECHNOLÓGIÁK ELFOGADÁSÁNAK VIZSGÁLATA A SZEREPELMÉLET SEGÍTSÉGÉVEL
}

Az önkiszolgáló technológiák (self-service technologies) használata a szolgáltatóiparban az információtechnológia és a telekommunikáció fejlódésével mindennapi életünk részévé vált. Kevés olyan szolgáltatóágazatot lehet találni, amely valamilyen módon ne alkalmazná a vevôi önkiszolgálás lehetốségeit. A szerzók cikkükben bemutatják e technológiák alkalmazásának lehetôségeit, kitérnek elônyeikre és hátrányaikra, valamint egy kutatás segítségével választ kívánnak adni arra a kérdésre, hogy az önkiszolgáló technológiák használata során a fogyasztónak milyen félelmekkel, szorongásokkal kell szembenéznie, s hogy a fogyasztói szerepek pontos meghatározása ezt mennyiben oldhatja. Kutatásuk mintaválasztása lehetóséget ad arra is, hogy megvizsgálják a generációs különbségeket a fiatalabb és az idôsebb használók között. Eredményeik alapján elmondhatják, hogy a feltételezett különbség a korcsoportok között nem jelentôs, sokkal inkább a fogyasztóhoz köthetố egyéni tényezók játszanak szerepet az önkiszolgáló technológiák elfogadásában. A fogyasztó számára a szerepek (szkriptek) pontos meghatározása nagyban segítheti az önkiszolgáló technológiák fogyasztói elfogadását és használati hatékonyságát.

\section{Kulcsszavak: szolgáltatásmarketing, önkiszolgáló technológia, szerepelmélet}

Vargo és Lush (2004) szerint az egyénre szabottság azzal kezdôdik, hogy a fogyasztónak kontroll van a kezében afelett, hogy a folyamatokat a maga igényeihez szabja. Bár eredeti céljuk e gondolattal nem feltétlenül az önkiszolgáló technológiák terjedésének indoklása volt, mégis remekül megállja a helyét e kontextusban is. Az internet, a telekommunikáció és az információs technológia fejlődése nagy erejú változásokat hozott a szolgáltatóiparban, mindez mégsem lett volna elegendő ahhoz, hogy mindennapjainkat ennyire áthassa az önkiszolgálás, ha nem jelenik meg annak az igénye, hogy kézbe vehessük ügyeink intézését.

Cikkünkben bemutatjuk, hogy miért válhattak az eredetileg költségcsökkentő céllal kialakított önkiszolgáló technológiák mára ennyire népszerúvé, hogy melyek azok a vállalati és fogyasztói tényezók, amelyek hozzájárultak e gyakorlat elterjedéséhez. Noha a nemzetközi szakirodalomban a témát jelentôs érdeklódés kíséri, magyar kutatási összefoglalók és eredmények még igen ritkák. Azok a kutatások, amelyek a technológia hatásával foglalkoznak, elsôsorban a vállala- ti múködésre való hatását vizsgálták (Keszey, 2007; Drótos - Szabó, 2001; Drótos - Móricz, 2012; Duma - Erdős, 2008), a fogyasztói oldal egyelőre nem került elôtérbe. Ezt a hiányosságot kívánjuk pótolni cikkünkkel, teret adva nemcsak saját kutatási eredményeink bemutatásának, hanem a téma nemzetközi szakirodalmi összefoglalásának és a fóbb kutatási irányok ismertetésének. Empirikus kutatásunk egyrészt kísérletet tesz a fogyasztói elégedettség és elégedetlenség okainak feltárására, másrészt a forgatókönyv-elmélet alkalmazásával egy olyan új keretbe helyezi az önkiszolgáló technológiák kutatását, amely mind ez idáig nem került előtérbe.

$\mathrm{Az}$ önkiszolgáló technológiák fogalmát először Meuter et al. (2000: 50. o.) definiálta „Olyan technikai felületek, amelyek lehetôvé teszik az ügyfelek számára, hogy egy szolgáltatást független és közvetlen munkavállalói részvétel nélkül vegyenek igénybe."

Történelmi kitekintést téve elmondhatjuk, hogy az elsố önkiszolgáló rendszerek már igen régen megjelentek. Clarence Saunders 1916-ban alapította meg a 
világ első önkiszolgáló boltját Piggly Wiggly néven az amerikai Tennessee államban, melyet franchise-rendszerben terjeszteni is kezdett, nagy sikerrel (Salomann et al., 2007). Ezt követően, csupán 1949-ben jelent meg Amerikában az elsố automata benzinkútállomás. Több mint egy évtizeddel ezután a Bell System feltalálta azt a technológiát, mely alapjául szolgál a jelenleg is népszerú IVR-rendszereknek, azaz telefonos ügyfélszolgálatoknak. A technológia ilyen jellegú használata azonban még váratott magára a nyolcvanas évekig. Hasonló nehézségekkel indult a manapság már szinte mindennapi használati eszközzé vált ATM-automaták története. Az első darabokat az IBM fejlesztette ki, és 1972 decemberében kezdték meg múködtetésüket. Népszerútlensége miatt mégis bevonták, és sokáig a vevók csak mint a kártyát elnyelô szörnyre tekintettek. Az elsố reptéri bejelentkezô kioszkok a '90-es évek közepén jelentek meg, mégis csak a 2000-es években vált általánossá alkalmazásuk. E történetek felidézése alkalmat ad arra, hogy megvizsgáljuk, mitôl lesz egy önkiszolgáló technológiai újítás bevezetése sikeressé vagy sikertelenné, s melyek a fogyasztói elfogadás kulcstényezői.

\section{Az önkiszolgáló technológiák típusai}

Az önkiszolgáló technológiák csoportosítását két dimenzió mentén tehetjük meg, egyrészt funkció, másrészt felület alapján (Bitner et al., 2002). Célját tekintve az önkiszolgáló rendszerek szolgálhatnak a vevố tájékoztatására, „tanítására”, másodsorban a vevoószolgálat kialakítására, harmadrészt pedig tranzakciók végrehajtására. Az első esetben a vevới információszerzést és a vevő́k edukálását könnyíti meg az önkiszolgáló technológia. Ha kíváncsiak vagyunk például arra, hogy egy bank milyen számlakondíciókat kínál, akkor megnézzük az interneten, ahelyett, hogy bemennénk a bankba, és az ügyintézótól kérdeznénk meg a feltételeket. Hasonlóképpen, amikor szeretnénk megtudni, hogyan múködik a szolgáltató internetbanki felülete, akkor megnézünk róla egy demót. A második eset már nem puszta információszerzés, hanem valamilyen módon a saját, személyes problémánk, a szolgáltatóhoz kötődó tranzakcióinkkal kapcsolatos érdeklődés. Klasszikus példája ennek, amikor az interneten nyomon tudjuk követni, hogy rendelésünk éppen hol tart (Fedex), de ide tartozik minden olyan on-line banki ügyintézés, amikor számlánk állásával kapcsolatos információkra van szükségünk. A harmadik esetben az ügyfél már maga intézi ügyeit, azaz tranzakciókat hajt végre önállóan: átutal, szobát foglal, bejelentkezik a repülőgépre stb. Nyilvánvalóan ez utóbbi igényli a fogyasztó részéról a legmagasabb bevonódást, a szolgáltató részéról pe- dig a legszofisztikáltabb megoldásokat. Salomann et al. (2006) kutatásaik alapján arra az eredményre jutottak, hogy a megkérdezett vállalatok $71 \%$-a tranzakció, 66\%-a vevôszolgálat és 39\%-a tájékoztatás céljából használja az önkiszolgáló technológiákat.

A felületet tekintve az önkiszolgáló technológiák alkalmazhatnak telefonos, internetalapú, kioszkalapú (pl. ATM vagy reptereken a self-check-in) és CD/DVD (elsősorban vevối edukációra) alapú önkiszolgálást. A már idézett kutatás eredményei szerint a vállalatok 96\%-a internet alapon, 50\% telefonon keresztuil, 23\% interaktív kioszkokon keresztül kínál önkiszolgálást, és csupán 16\%-uk használ CD/DVD-t a rendszerhez.

A hagyományosan elterjedt besoroláshoz hozzátennénk, hogy az elmúlt évek során az okostelefonok terjedése ismét alapjaiban változtatta meg az önkiszolgáló technológiák napi múködését, és a mobiltechnológia egy olyan új felületet adott az eddig meglévőkhöz, amely fejlesztése a vállalatok számára elsődlegessé vált az utóbbi években.

Természetesen egyfajta funkció többféle felületen is megjelenhet, bár a technológiaalapú önkiszolgáló rendszerek legtöbbje ma már az interneten keresztül valósul meg.

\section{Az önkiszolgáló rendszerek elốnyei}

Az önkiszolgáló rendszerek megjelenése, s egy megfelelôen kialakított rendszer bevezetése a vállalatok számára jelentôs elônyöket biztosíthat.

- Az egyik legvonzóbb előny a vállalatok számára a költségek csökkentése (Dabholkar,1996). A technológiaalapú önkiszolgáló rendszerek humánerơforrás- $\mathrm{s}$ múködésiköltség-megtakarítást jelenthetnek, így bevezetésük hosszabb távon igen megtérülő a vállalatok számára.

- Számos esetben a fogyasztók megkövetelik a technológiaalapú önkiszolgáló rendszerek jelenlétét, épp ezért mára már a versenyelőny egyik eszközévé váltak ezek a technológiák. A megfelelố múködésú rendszer így növelheti a fogyasztói elégedettséget, s hosszabb távon a lojalitás egyik támogató tényezőjévé válhat a vállalat számára (Hsieh, 2005).

- Az önkiszolgáló rendszerek bevezetése lehetőséget nyújt a vállalatok számára, hogy újabb fogyasztói csoportokat érjenek el szolgáltatásaikkal (Bitner et al., 2002). Példának említhetốk az olyan szolgáltatások, melyek földrajzi helyhez kötöttek, ám az internetalapú rendszerek ezeket a határokat eltörlik, így egy banki szolgáltatás már szinte a világ bármely pontjáról elérhetôvé válik. 
Ezáltal egyszeri befektetés révén globálissá válik a piac, ami igen vonzóvá teszi ezt az elosztási csatornát.

- Fontos azonban hozzátenni, hogy a vállalatok számára nemcsak költség- és időmegtakarítást jelentenek a rendszerek, hanem stratégiai szinten is jelentős előnyöket adnak. Azok a vállalatok, amelyek magas színvonalon képesek az önkiszolgáló rendszereket kialakítani és múköödetni, innovációs vezetốk lehetnek, mely jelentôs versenyelónyt jelenthet a piacon (Salomann et al., 2006).

- A technológia használatával könnyú információkezelhetőség érhetô el, hiszen a papírmunka jelentős része elkerülhetô vele. Manapság már egy repülójegy vásárlásakor csak a legfontosabb dokumentumokat nyomtatják ki a fogyasztók, ám adataik a rendszerben elektronikusan szerepelnek.

- Az alkalmazottak számára is elónnyel szolgálhat a rendszer, ami közvetve a vállalatra is pozitív hatással van. A dolgozók munkaköréból kiesik egy-egy részmunka (pl. adminisztráció), így olyan feladatokkal foglalkozhatnak, amelyek fontosabbak, s a fogyasztók kényelmét szolgálják. Így például, ha egy hotelben a bejelentkezést kioszkokon keresztül végzik, a recepciósok koncentrálhatnak a vendégek üdvözlésére, s ajánlhatnak nekik programokat, növelve a szolgáltatás színvonalát.

- Az önkiszolgáló rendszerek magas szintú személyre szabottságot nyújthatnak, hiszen a rendszer megjegyzi a használó adatait, így akár tanácsadást is adhat számára (Glushko Nomorosa, 2012). Jól megtervezett programokkal az elózetesen megnézett internetes oldalak az elôzetes fogyasztói rendelések alapján képesek beazonosítani a vevói profilt, továbbá statisztikai adatokkal dolgozva ajánlanak az igényhez megfelelő szolgáltatásokat. Klasszikus példája ennek az Amazon.com, de ugyanígy múködik a Hilton hotelekben a bejelentkező kioszk, amely a már ismert vendég szobapreferenciái alapján automatikusan ugyanazt a szobát ajánlja fel.

\section{Önkiszolgáló rendszerek fogyasztói elfogadása}

Természetesen az önkiszolgáló rendszerek sikerességének kulcsa az, hogy a fogyasztók is elfogadják, és használják ezt a lehetőséget. Ehhez elengedhetetlen, hogy ôk is számos ponton profitálhassanak az önkiszolgáló rendszerek nyújtotta előnyökboól. Az önkiszolgáló technológiák kutatásának egyik legalapvetốbb kérdése a fogyasz- tói elfogadás folyamatának és befolyásoló tényezôinek a feltárása. Több jelentôs kutatási irányzat fejlődött ki a 90-es évek végétől, amelyekhez azóta számtalan újabb és újabb kutató és eredmény kapcsolódott.

\section{Elfogadási folyamat}

A kutatások egyik fó áramlata az innováció terjedésének elméletéhez és a fogyasztó elfogadási folyamatához (diffusion of innovations; Rogers, 1995) kötôdôen vizsgálja az önkiszolgáló technológiák elterjedését (Bitner et al., 2000; Bitner et al., 2002; Meuter et al., 2000; Meuter et al., 2003; Meuter et al., 2005). Elsố kutatásaikban azt vizsgálták, hogy melyek azok a tényezôk, amelyek sikerhez vagy sikertelenséghez vezetnek a fogyasztói használat során, majd kialakítottak egy modellt, amelyben az elfogadás folyamatát írták le a rogersi elmélet alapján. Késóbb ezt a modellt kiegészítették azokkal a tényezókkel, amelyek a folyamatkipróbálás szakaszához köthetők. Parasuramann (2000) kutatási eredményeire építve beillesztették modelljükbe a „technológia elfogadására való készenlét” (technology readiness) változóját, amely így központi konstrukcióként (fogyasztói felkészuiltség) közvetít a fogyasztó és az innováció jellemzối mint független változók és a kipróbálás mint függó változók között. A fogyasztói felkészültség elemei a technológia alkalmazása során kialakított szerep egyértelmúsége (ez kutatásunkban jelentôs szerepet kap a késốbbiekben), a képesség a technológia alkalmazására, illetve a külsố és belső motiváció. A négy változó közül az eredmények alapján elmondható, hogy a szerepegyértelmúség és a külsố motiváció volt a kipróbálásra a legnagyobb hatással.

Az 1. ábrán látható, hogy a modell eredményváltozója az elfogadási folyamat, amelyból kiemelt fontosságot kap a 4. lépés, a kipróbálás. Azt is látni kell azonban, hogy mind az azt megelőző (ismeret, adatgyưjités, értékelés), mind az azt követő lépések (ismételt használat, elkötelezettség) fontosak ahhoz, hogy a fogyasztó aktív használójává váljon a technológiának (modell jobb oldali része).

Mind a fogyasztói elfogadás folyamatának, mind a fogyasztói felkészültség tényezóinek fontos magyarázó változói az innováció jellemzói és a fogyasztó egyéni tulajdonságai. Az eredmények azt bizonyítják, hogy mind az innováció, mind a fogyasztó egyéni jellemzői hatással vannak a kipróbálásra, de nem direkt módon, hanem a fogyasztó felkészültségén keresztül. Tehát hiába vannak meg az innovációnak a kipróbálást ösztönzô tulajdonságai (pl. relatív előny vagy kompatibilitás), ha a fogyasztó nem felkészült az alkalmazásra, például azért, mert nem tiszta számára a tóle elvárt szerep. Ebben az esetben a kipróbálás valószínúsége csökkenni 
Az önkiszolgáló rendszerek fogyasztói kipróbálást befolyásoló tényezői

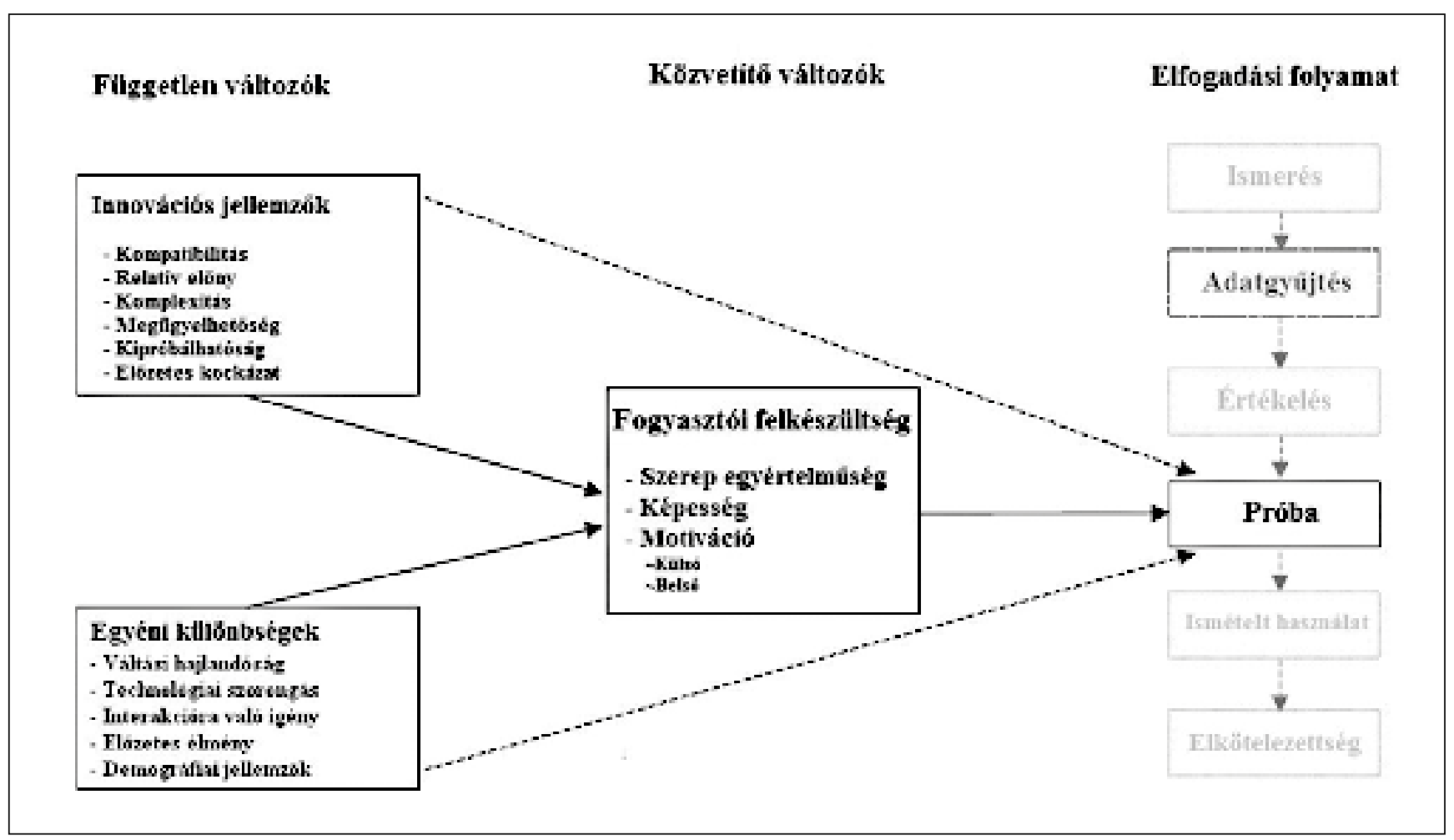

Forrás: Meuter, M. - Ostrom, A. - Roundtree, R.I. - Bitner, M.J. (2005): Choosing Among Alternative Service Delivery Modes: An Investigation of Customer Trial of Self-Service Technologies, Journal of Marketing, 63. o.

fog. Ez a kutatás rávilágít a fogyasztó technológiai felkészültségének központi szerepére, amely eredményt késóbb több más kutató is alátámasztotta (Elliott et al., 2013; Lin - Chang, 2012).

\section{A technológiaelfogadás modellje (TAM)}

A kutatási eredmények másik vonulata a használati szándékok és attitúdök alaposabb vizsgálatát kísérelte meg (Curran et al., 2003; Dabholkar, 1996; Dabholkar - Bagozzi, 2002). Ezekben a kutatásokban arra a feltételezésre építettek, amely szerint a pozitív attitúd vezet el a használati szándékhoz (TAM-modell - technology accaptance model, Davis, 1989; Davis et al., 1989). A TAM-modell eredeti feltételezése szerint a fogyasztó pozitív attitúdjének kialakulásához elsôsorban az vezet, hogy a fogyasztó milyennek észleli a technológia használhatóságát és a használat egyszerúségét. A TAM-modell alapját az ,átgondolt cselekvés elmélete” alkotja (Theory of Reasoned Action: Ajzen - Fishbein, 1980), amely szerint az attitúdök nem közvetlenül a magatartást befolyásolják, hanem a cselekvési szándékot. A TAM-modell sok kutató számára jelentett kiindulópontot. Dabholkar és Bagozzi 2002-ben kiegészítette a modellt moderátorváltozókkal, amelyek segítségével egyrészt arra mutattak rá, hogy mely tényezốk befolyásolhatják a kapcsolatot a független változók (használat könnyúsége, teljesítmény, szórakoztatás) és az attitúd között, másrészt arra, hogy mely fogyasztóhoz kötődő és szituációs tényezók befolyásolják az attitúd hatását a használati szándékra (2. ábra). A kutatás fontos eredménye, hogy ráirányította a figyelmet a szituációs változók jelentőségére, ami további kutatásokat implikált (Wang et al., 2012), igazolva a kutatási irány fontosságát.

A két bemutatott kutatási modell rávilágít, hogy az önkiszolgáló technológia fogyasztói elfogadásának és használatának számtalan befolyásoló eleme van, ezek egy része a fogyasztóhoz magához kötődik, akár demográfiai, akár pszicho-szociális jellemzóként, akár a technológia használatához való hozzáállásaként. Másrészrooll sok olyan tényező van hatással az attitúdre, amely magához a technológiához kötődik, annak komplexitásához, kockázatosságához, használati egyszerúségéhez, teljesítményéhez vagy szórakoztató mivoltához. Fontos megjegyeznünk, hogy ezek a tulajdonságok nem objektív jellemzói a technológiának, hanem mindig a fogyasztó által érzékelt tulajdonságai. Mindezeken túl nem lehet eltekinteni a szituációs tényezóktől sem, amelyek erôteljesen megváltoztathatják a hatások erősségét. 
Az eddigiekben bemutatott kutatási modellek elsốsorban arra vonatkoztak, hogy az egyes önkiszolgáló technológiák milyen fogyasztói fogadtatásra találhatnak. Meg kell azonban jegyeznünk, hogy ezek a technológiák sohasem önmagukban állnak, hanem mindig valamilyen más alternatív kiszolgálási lehetőségekkel összehasonlítva adnak a fogyasztónak értéket. Fontos tehát annak vizsgálata, hogy a többi alternatívához viszonyítva hogyan fogadja a fogyasztó az önkiszolgáló opciót. Ennek a kérdésnek a megválaszolására tett kísérletet Curran és Meuter (2005), akik az egyes banki önkiszolgáló technológiákat hasonlították össze a TAM elméleti keretén belül. Eredményeik arra mutatnak rá, hogy a modell eltéró összefüggéseket mutat a különféle technológiák esetében. Míg az ATM és a telefonos banki ügyintézés során a technológia használhatósága és egyszerúsége vált fontossá, addig az on-line bankolás esetében semmi más nem mutatott szignifikáns összefüggést az attitúddel, csak a kockázatosság. Eredményeik több szempontból is érdekesek. Egyrészt felhívják a figyelmet arra, hogy az önkiszolgáló tech-

A TAM-modell moderátorváltozókkal

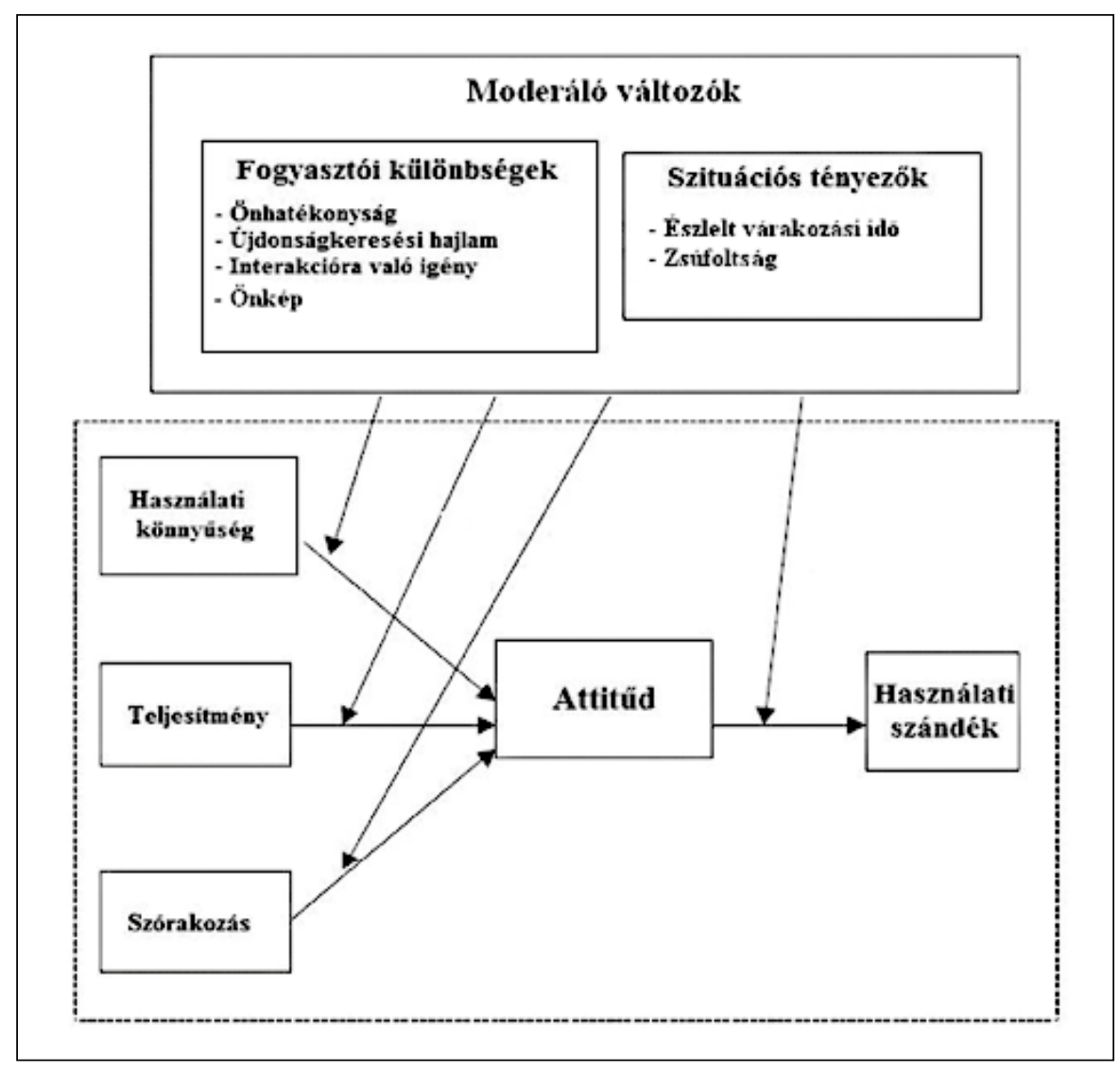

Forrás: Dabholkar, P. - Bagozzi. P.R. (2002): An attitutional Model of technology-based self-service: Moderating effects of consumer traits and situational factors. Journal of Academy of Marketing Science, (30): 186. o. nológiák maguk is nagy változatosságot mutatnak, ennek vizsgálata lényeges. Másrészt, hogy a technológiai újításoknak is lehet termékéletgörbéje, és a nagyon új technológia esetén más tényezók fontosak, mint a már bevett, és bizonyítottan jó technológiák esetében (emlékezzünk csak az ATM történetére, amikor is az elsố gépeket vissza kellett vonni, mert a fogyasztók túlzottan kockázatosnak érzékelték, hogy a gép elnyeli kártyájukat).

\section{Co-creation - közös értékteremtés}

Míg az innovációk elterjedése, illetve a technológiaelfogadás modellje a technológia használóját kevéssé tekinti a folyamat aktív részesének, addig a kutatásoknak egy új irányzata rámutat arra, hogy a technológia elfogadása során a használók azt aktívan alakíthatják, s így a kialakult technológia egyfajta „,közös" produktum lesz. A technológia használójának felhatalmazása (empowerment) teljesen új irányt nyit meg a technológiaelfogadás kutatásában. Ebben az elméleti keretben nem is beszélhetünk a technológia elfogadásáról, sokkal inkább befogadásáról. Ennek az irányzatnak a legújabb elméleti irányzata az információs technológia szakirodalmában a „szociomaterialista” (sociomateriality) megközelítés, amely arra utal, hogy a technológia beágyazódik a társadalomba, és mára nem lehet elkülönítve kezelni a társadalmi folyamatokat a technológiai folyamatoktól (Orliowsky - Scott, 2008; Leonardi, 2013). Hasonló eredményre jutottak azok a kutatások, amelyek a co-creation, közös vevối értékteremtés (Prahalad - Ramaswamy, 2000; Vargo Lush, 2004) platformjáról kiindulva vizsgálták a technológiák elfogadását. Noha az innovációra és különösen az önkiszolgáló technológiákra vonatkozóan igen kevés kutatási eredményt találhatunk, amelyek ezen elméleteket alkalmazzák, ezekból is látható, hogy kiemelkedő jelentőséget kap a vevői edukáció. Hilton et al. 2013-ban közölt kutatásukban kvalitatív, félig strukturált interjúk segítségével kívánták megérteni, hogy milyen előnyei szár- 
mazhatnak a fogyasztónak az önkiszolgáló technológia során a vevôi részvételból, a közös értékteremtésból. Eredményeik a szolgáltatásdomináns logika premiszszáiból kiindulva azt bizonyítják, hogy akár kockázata is lehet a vevố részfoglalkozású munkaerôként való alkalmazásának (,aktívügyfél-politika" Veres, 2009: 203. o.), és a vállalatnak jelentôs erófeszítéseket kell tennie a vevő képzésére, akárcsak a hagyományos esetben az alkalmazottakéra. Ezek az eredmények összhangban vannak a már idézett magyarországi vállalati kutatásokkal, ahol szintén kiemelkedett a vállalaton belül a képzés fontossága (Keszey, 2007).

Az önkiszolgáló technológiák kutatása során sokféle változó és modell került kialakításra, de többek között Hiltonék kutatása is bizonyítja, hogy a fogyasztó mélyreható vizsgálata sok esetben elmaradt. Jelen cikkünkben egy olyan tényezôre szeretnénk ráirányítani a figyelmet, amely ugyan része az eddigiekben bemutatott kutatási modelleknek, de szükséges a mélyebb megértése ahhoz, hogy valóságos szerepét értékelni tudjuk az önkiszolgáló technológiák fogyasztói elfogadása/befogadása során. Ez a tényezó a fogyasztói szerepekhez kötődik.

\section{A fogyasztói szerep és a forgatókönyv-elméletek}

A fogyasztói szerep a szolgáltatás központi eleme, melynek megértésében a forgatókönyv-elmélet kiváló lehetőséget nyújt (Broderick, 1999; Grove - Fisk,1983; Grove - Fisk,1992). Megfelelő vizsgálattal lehetséges mérni a forgatókönyvek minőségét, megmutatni az előzményeket, majd kimutatni a kapcsolatot a forgatókönyv egyezôsége és a fogyasztói teljesítmény, valamint elégedettség között (Bateson, 2002a). A fogyasztói részvétel az önkiszolgáló rendszereknél az átlagosnál is nagyobb hangsúlyt kap, épp ezért releváns megvizsgálni múködési mechanizmusát.

A kognitív pszichológia szerint az emberi memóriában sémák, azaz kognitív struktúrák vannak tárolva, melyek tárgyakhoz vagy témákhoz kapcsolódnak (Bozinoff - Roth, 1983). A séma egyes részeihez egy meghatározott inger kapcsolódik, amely egy különleges tapasztalat, és az általános ismeretek közti kapcsolatot dominálja. Ha az egyén egy szituációval szembesül, a séma a hosszú távú memóriában referenciaként szolgál, hogy az ember képes legyen értelmezni és befogadni az adott helyzetet. A forgatókönyv-elmélet egyfajta eszköznek tekinthető, mely az egyén számára lehetôvé teszi, hogy a környezetból származó nagy mennyiségú információból, a szelektív észlelés segítségével, a mindennapi információk kiválasztására és a tudás éppen szükséges részének összpontosítására legyen képes.
A sémák négy csoportba sorolhatók, nevezetesen saját sémák (amelyek információt tartalmaznak a saját személyiségról), személysémák (amelyek középpontjában az emberi vonások vannak, melyek különböző típusú emberekre érvényesek), szerepsémák bizonyos helyzetekben (amelyek tartalmazzák az embereket és jellemzó szerepeiket egyes társadalmi szituációkban) és eseménysémák, azaz szkriptek (forgatókönyvek) (Erasmus et al., 2002). Ezek a szkriptek jelentik az események várható sorrendjét egy adott helyzetben. A forgatókönyv tehát egy séma, amely fizikailag egymás utáni sorrendben leírt eseményeket tartalmazó adatok sora. Ezeket az adatokat a hosszú távú memóriában tároljuk. Az önkiszolgáló rendszer példáján egy szkript az egyes jelenetek/elemek, mint például egy bankautomatához való odalépés, a bankkártya bevitele, a pénzkivevésig jutó lépések sorozata, melyben a hely, a többi ember reakciója szignifikáns részét képviseltetheti a forgatókönyvnek. Természetesen a forgatókönyvek bizonyos tulajdonságokkal rendelkeznek. Egy adott szkript mindig ugyanazt a szereploót, kelléket, intézkedéseket tartalmazza, így egy specifikus képet adva az eseményról (Kenesei - Kolos, 2007).

A forgatókönyvek jelentôsége, hogy megszabadítja a fogyasztót attól a félelemtól, hogy nem tud megfelelni a rendszerhasználati követelményeknek, és segítségével egyben képessé tehetjük, hogy növelje a szolgáltatás hatékonyságát és minôségét. Természetesen minél nagyobb a fogyasztó részvétele a szolgáltatási folyamatban, annál jelentősebb irányítást kíván, ezért fontos az önkiszolgáló rendszereknél a fogyasztók fejében lévő szkriptek ismerete (Bateson, 2002b).

A szolgáltatásteljesítés a forgatókönyv-elmélet alapján a fogyasztó számára cselekvések sorozata, amelyek megadott sorrendben történnek. Egyértelmú, hogy az új, tapasztalat nélküli fogyasztó ennek nincs birtokában, miközben a tapasztalt vevő már előzetes élménnyel és tudással rendelkezik, s a több tapasztalat révén már egyre inkább szakértővé válik. A fő különbség továbbá az új és a szakértő fogyasztó között nemcsak tudásban van, hanem a tudás szervezettségében is, hiszen minél szervezettebb a tudás, annál hatékonyabban használható (Bateson, 2002a). Eszerint a memóriában tárolt szkriptek az idő múlásával, egyénre jellemzô folyamatos tanulással jól gyakorolt, rutinszerú események lesznek. Így valós élethelyzetben a szkriptek alkalmazása már automatikussá válik, tehát ezeket használják fel a helyzeti viselkedés aktiválásakor. Azért is különösen fontosak, mert megórzik a már megtett erôfeszítéseket, így a következő szituációban már nem kell újratanulni a már elvégzett lépéseket (Erasmus et al., 2002). 
Kérdésként merülhet fel, hogy vajon tényleg léteznek-e ilyen típusú elképzelések a fogyasztók fejében. Erre vonatkozóan Victorino et al. (2012) egy kísérletben bizonyította, hogy igenis vannak fogyasztói és szolgáltatói szkriptek, és ezeket a fogyasztók észlelik is.

Az önkiszolgáló rendszerek esetében a fogyasztó fejében lévô szkriptek vizsgálata során például érthetôvé válik a fogyasztó viselkedése a rendszerrel kapcsolatban, feltárhatók azok a pontok, amelyeket a fogyasztó hiányol, esetleg feleslegesnek tart, vagy nehézségekbe ütközik. A rendszerek tervezésénél is segítséget nyújthat, hiszen segítségével a szolgáltatók információt gyújjthetnek, hogy hol és milyen körülmények között érdemes a rendszereket felállítani. Mivel a szkriptek vizsgálata a használathoz kapcsolódó tudásról és/vagy elképzelésról is szolgáltat információt, a fogyasztó önkiszolgáló rendszerrel kapcsolatos edukációja is hatékonyabbá és specifikusabbá válhat, arra koncentrálva, ami tényleg fontos és hasznos a fogyasztó számára.

\section{Kutatási kérdések és a kutatás módszertana}

Kutatásunk célja, hogy mélyebben megértsük az önkiszolgáló rendszerek fogyasztói elfogadását, használatának motiváló tényezóit. Szeretnénk feltárni, hogy a magyar fogyasztók milyen attitúddel rendelkeznek a rendszerek iránt, az elfogadási folyamat mely szakaszában tartanak, s mi befolyásolja az elfogadásukat. Azonosítani szeretnénk az erősségeket, s a rendszer azon pontjait, melyek fogyasztói szemszögból fejlesztésre szorulnak. Emellett forgatókönyv-elméleti kontextusban vizsgáljuk, hogy mennyire vannak tisztában a fogyasztók saját szerepükkel a használat során, léteznek-e szkriptek a fogyasztók fejében, s ezek mennyiben járulnak hozzá a szolgáltatásélményhez. Ezek alapján szeretnénk következtetéseket levonni arra vonatkozóan, hogy milyen irányba kell fejleszteni, milyen iparágakban érdemes kibővíteni újabb bevezetésekkel, valamint hol kívánatos csökkenteni, esetleg átstrukturálni az önkiszolgáló rendszerek használatát.

Kutatásunk során azt is vizsgáljuk, hogy azonosíthatóak-e használatbeli különbségek a különböző életkorú felhasználók között, s ezek hogyan befolyásolják az elfogadást és a használatot.

Kutatási módszerünk a kritikus esetek technikája (CIT). E módszert a szolgáltatásokkal való találkozás (service encounter) vizsgálatára alkalmazzák, elsősorban a szolgáltató-vevő interakció elemzésére (a módszerról részletes leírás: Kolos - Kenesei, 2007). Esetünkben természetesen a hagyományos értelemben nincs vevő-alkalmazotti interakció, azonban „service encounter" nagyon is létezik. Az önkiszolgáló technológiák használata során a vevố ugyanis interakcióba lép a szolgáltatóval, csak nem egy élő személyen keresztül, hanem egy gépen (számítógép, ATM, check-in pult, pénztárgép stb.) keresztül. Ezek a szolgáltatásélmények alkalmasak arra, hogy a kritikus esetek módszerével vizsgáljuk meg óket, hiszen nagyon jól behatárolható eseményekról van szó, amelyek lehetnek nagyon emlékezetesek a fogyasztó számára.

Az interjúk mindig egy konkrét élményre vonatkoztak, s feldolgozásuk során a kvalitatív tartalomelemzés módszerét alkalmaztuk. A kódolás folyamán a szakirodalomból megismert fóbb csomópontokból indultunk ki, de az elemzés során folyamatosan figyelemmel kísértük az új szempontok megjelenését is, amelyeket az elemzésrészben minden esetben külön kiemelünk. Az elemzés során az eseteket próbáltuk minél mélyebben megérteni, és iteratív módon folyamatosan visszatértünk az adatokhoz az újabb elméleti szempontok vizsgálata során. Az esetleírásokat kiegészítette néhány általános kérdés, egyrészt a bevezetôben, a témába való bevezetésképpen, másrészt az interjú végén, elsősorban a forgatókönyvekre vonatkozóan.

Az adatgyuujjtés során 62 mélyinterjú készült, a minta kiválasztására önkéntes mintavételt alkalmaztunk. Az interjúk a válaszadók otthonában, vagy egy olyan helyen történtek (pl. munkahely), ahol lehetőségünk volt nyugodtan beszélgetni. Az interjúk fél-egy órásak voltak. Az interjúkat rögzítettük a késóbbi elemzés céljából. Az elemszám természetesen nem ad lehetôséget kvantitatív elemzésre, mégis - mivel elég számos a megkérdezettek köre - alkalmanként megengedjük a nagyobb ívú következtetéseket, amennyiben a minta nagyobb részére igazak megállapításaink. A mintavétel során a demográfiai jellemzóket tekintve két fó csoportot definiáltunk, a fiatal (18-30 év) és a szenior (50+) korosztály fogyasztóit különböztettük meg: 32-32 darab mélyinterjút készítettünk mindkét csoportban. A két korcsoport megkülönböztetésének alapjaként szolgált, hogy az idôsebb fogyasztókat tradicionálisan eltéró jellemző́kkel írják le a technológiai alapú szolgáltatásoknál. Ennek oka többek között a kor elôrehaladtával bekövetkezett változások, például a lassabb információbefogadás, másrészt pedig az, hogy az idősebbek kevésbé magabiztosak a technológia használatakor (Spotts - Schewe, 1989; Zeithaml - Gilly, 1987; Kolos, 2008).

Célunk tehát az eddig megfogalmazottakon túl, hogy felfedjük a vizsgálat középpontjába helyezett két korosztály attitúdjében, használati motivációiban és szerepfelfogásában meglévő különbségeket. 


\section{Eredmények}

Az interjúk alapján kiderült, hogy a megkérdezettek többsége már az önkiszolgáló rendszerek említésénél nagyrészt tisztában volt a fogalommal, s többségük a szolgáltatószemélyzet hiányát említette a technológia legfőbb tulajdonságaként. A megkérdezettek jelentôs része az önkiszolgáló technológiákat az internetes ügyintézéssel, vásárlással azonosította.

\section{Használat}

A válaszadók által felsorolt és rendszeresen használt önkiszolgáló technológiák köre a várakozásainkat felülmúlóan széles volt, ami az interjúk többségénél 5-7 körüli példát jelentett. Azon interjúalanyok számára, akik nehezebben tudtak példát mondani, segítségül felsoroltunk néhányat (általában az elméleti részben bemutatott kategóriákból egy-egy darabot), s utána már maguktól számoltak be a használt önkiszolgáló technológiákról.

A felsorolt önkiszolgáló technológiákat korosztályok szerint három csoportba tudtuk besorolni. Voltak olyanok, amelyeket tipikusan csak a fiatalabbak említettek, voltak melyeket a szenior korosztály tagjai, s volt egy közös halmaz, amelyek használata mindkét csoportra jellemző volt. Ezek közül a legnépszerúbbeket szemlélteti az 1. táblázat. megtalálható volt a válaszok között. A használati módok közül (internet, telefon, kioszk, CD/DVD, mobiltelefon) egyértelmúen az internet a legnépszerúbb, ez mind a fiatalok, mind a szenior korosztályban elmondható. Közös használati pont volt az internetes repülôjegy-foglalás, on-line vásárlás, valamint az idốpontfoglalás. Ezenkívül a fiatalabbak szívesen intézik banki ügyeiket on-line, rendelnek ételt s intézik jelentkezéseiket is ezen a módon. Az 50 év felettiek többsége (akadtak persze kivételek) az on-line banki ügyintézést biztonsági okok miatt nem használja, de szívesen vásárolnak színházjegyet, kiállításjegyet s kötik meg biztosításaikat ilyen formában. $\mathrm{Az}$ internetet követóen a fiatalabb csoportban a kioszkok következtek használati gyakoriság szempontjából, $\mathrm{s}$ végül pedig a telefonon keresztül történô szolgáltatásnyújtás. Az idősebbeknél azonban ez fordított sorendben jelent meg, így ôk a telefonos önkiszolgálást részesítik előnyben, s harmadsorban a kioszkokat.

A 30 alatti korosztály megkérdezettjei közül többen említették az okostelefonokra letölthető önkiszolgáló szolgáltatásokat, mint például ételrendelés, taxirendelés, de már az idôsebbek is sokszor használják alkalomadtán mobiljukat hasonló célra, például parkolódíj befizetésére vagy autópálya-matrica vásárlására.

Az interjúk alapján a használat gyakoriságáról kirajzolódó kép szerint a fiatalabbak gyakrabban élnek az önkiszolgálás adta lehetôségekkel. A használati gyako-

1. táblázat

\section{Az említett és használt önkiszolgálótechnológia-típusok korcsoportonként}

\begin{tabular}{|c|c|c|}
\hline Fiatal korosztály & Mindkét korosztály & Szenior korosztály \\
\hline - On-line bankolás & - Rep. jegyfoglalás & - Színházjegyfoglalás \\
\hline - Mozijegyfoglalás & - ATM & - Autópályamatrica-vétel sms-ben \\
\hline - Ételrendelés interneten/telefonon & - BKV-jegyautomata & - Parkolójegyes automaták \\
\hline - Koncertjegy & - Interaktív térképek & - Kiállításra jegyvétel interneten \\
\hline - On-line rep. jegybecsekkolás & - Telefonos ügyintézés & - Biztosításkötés interneten \\
\hline - Reptéri kioszkbecsekkolás & - On-line vásárlás & - Hotelbecsekkolás \\
\hline - Vonatjegyvétel interneten & - Internetes idópontfoglalás & \\
\hline - Ügyfélszolgálati chat interneten & - On-line számlabefizetés & \\
\hline - Paypal & - Önkiszolgáló pénztár & \\
\hline - Nyelvvizsga/felvételi on-line jelentkezés & & \\
\hline
\end{tabular}

Fontosnak tartjuk kiemelni, hogy a megkérdezettek mindegyike használt és folyamatosan is használ különféle önkiszolgáló technológiákat, s ez kortól függetlennek bizonyult.

Összességében az önkiszolgáló rendszerek elméleti keretében tárgyalt három típus közül (tranzakció, információszerzés, vevôszolgálat) a tranzakciót említették legtöbbször, de a tájékozódás és a vevőszolgálat is riságot érintő kérdésekre a válaszok igen eltérőnek bizonyultak. Természetesen ez szolgáltató- és életmódfüggó is, ám többségében a megkérdezett fiatalok úgy nyilatkoztak, hogy napi rendszerességgel vesznek igénybe önkiszolgálást, míg az idősebbek csoportjánál ez heti 1-2 alkalmat jelent csupán. Azonban az idősebbek is egyre jobban igyekszenek beépíteni mindennapjaikba az effajta rendszereket, elsôsorban sokoldalú előnyeik miatt.

\section{VEZETÉSTUDOMÁNY}




\section{Attitüd}

Az önkiszolgáló rendszerek iránti attitúd vizsgálatának eredménye alapján elmondhatjuk, hogy igen pozitív volt a megítélésük a megkérdezettek között. Szinte kivétel nélkül általánosságban elégedettek az önkiszolgáló technológiák használatával, s úgy gondolják, a jövő́ben ez a szolgáltatásnyújtási mód fejlődni fog. Majdnem minden interjú során elhangzott olyan mondat, melyben érezni lehetett az érzelmi kötődésüket e rendszerekhez. Sokan hálásak az előnyökért, s szívesen veszik használatba óket, még ha kezdetben nem is magabiztosan álltak hozzájuk. Az érzelmi kötődést kifejező mondatokra például szolgálnak a következók:

„A mindennapjaim része, imádom óket.” (nó, 27 év)

„Megkönnyíti az életemet, hiányoznának, ha nem lennének." (nő, 22 év)

„Rajongok az internetes vásárlásokért.” (nô, 56 év)

Pozitív attitűdre következtethetünk továbbá abból is, hogy amikor az elônyökre és hátrányokra kérdeztünk rá, a megkérdezett alanyok közül mindenki több elônyt sorolt fel az önkiszolgálással kapcsolatban, mint hátrányt. A két csoport között azonban kissé eltérőek voltak a hagyományos szolgáltatási csatornával szemben említett elónyök.

A fiatalabbak az egyszerúséget, a gyorsaságot, a könnyư elérhetôséget, illetve a hatékonyságot emelték ki, mint pozitívumot. A szenior korosztály a kényelmet tekinti legfőbb elônynek, s élvezik az észlelt kontrollt.

A negatív attitúdök kialakulásában fontos szerepe van a bizalom hiányának. Sokan - különösen az idôsebbek közül - nem bíznak abban, hogy a biztonságot megórizve használhatók az önkiszolgáló rendszerek.

„Néha szorongok fizetéskor.” (nô, 56 év) ,,Mindig dobog a szívem, a pénzfelvételkor." (nô, 58 év)

Szinte mindenki hallott már ismerőseitôl, rokonaitól történetet a bankkártyák adataival való visszaélésekról, ami kockázatérzetet kelt a fogyasztókban. A fiatalok többsége általánosságban nem tartja bonyolultnak az önkiszolgáló technológiákat.

„A legtöbbször minden lépés értelmesen le van írva, csak el kell olvasni az embernek, nincs ebben semmi ördöngösség." (férfi, 20 év)

A szenior megkérdezettek többsége azonban úgy érzi, szükséges egy bizonyos fokú tudás a magabiztos és pontos használathoz:

„Nem hatelemiseknek találták ki." (férfi, 58 év)

Közös jellemző volt minden megkérdezettet együttvéve, hogy a bonyolultság fokát a fogyasztó saját technológiai jártasságához viszonyítja. Ebból kifolyólag, kortól függetlenül említették többen, hogy a technológiai tudásuk miatt olykor kevesebb magabiztossággal használják, bonyolultabbnak tartják. A rendszer észlelt komplexitása és a fogyasztó magabiztossága mindenképpen hatással van hozzáállásukra, fóként a szenior korosztály tagjai érzik úgy, hogy sokat kell tanulniuk a használathoz.

„, Mi nem ebbe születtünk bele, nekünk tanulnunk kell, de végül is legtöbbször szívesen csináljuk." (nő, 57 év)

Összességében a megkérdezettek döntô többsége pozitív attitúddel és véleménnyel van e rendszerekről, s nagy lelkesedéssel használja ôket.

\section{Az elégedettség és elégedetlenség forrásai}

A mélyinterjúk központi részében a megkérdezettek olyan eseteket meséltek el, melyek rendkívül elégedetté vagy rendkívül elégedetlenné tették óket az önkiszolgáló rendszerek használatakor. Az esetekról a lehetố legrészletesebb módon számoltak be a könnyebb elemezhetôség és a háttérben meghúzódó okok feltárása érdekében. Hozzá kell azonban tennünk, hogy a kritikus esetek közül az elégedetlenséget okozó példák felidézése átlagban könnyebbséget jelentett a megkérdezettek számára, s akadt néhány olyan résztvevő, aki rendkívüli elégedettséget okozó esetet nem is tudott azonosítani.

A kritikus eseteket érdemes csoportokba sorolni, hiszen könnyebben azonosíthatók lesznek a problémát, illetve az elégedettséget okozó szempontok. Az elemzés alapjául Meuter et al. (2000) csoportosító ismérveit használtuk, elfogadva azok relevanciáját. Az elemzés során a magyar önkiszolgáló rendszerekkel kapcsolatos fogyasztói reakciókat vizsgáljuk az adott elemzési kereten belül, a két korosztály eltéréseire vagy azonosságára koncentrálva. Azokban az esetekben, amikor az eredeti elemzési keretbe nem illeszkedő szempontok merültek föl, azokat külön kiemeljük és az elemzés végén bemutatjuk.

\section{Elégedettségre okot adó tényezók}

\section{Megoldotta a fogyasztó problémáját egy intenzív szituációban}

Ezen esetek során a fogyasztók olyan történetekról számoltak be, melyek során egy fokozott szükséglet keletkezett a szolgáltatás igénybevételére, $\mathrm{s}$ ebben a helyzetben az önkiszolgáló technológia jelentette számukra a megoldást. Itt a rendszernek legtöbbször azon elônyeit használták ki, mely szerint bármikor elérhetô és bárhonnan. Voltak, akiknél a gyors készpénzfelvétel jelentett segítséget:

„Késésben voltam egy szombat esti összejövetelról, mikor észrevettem, hogy otthon hagytam a pénztárcám. Tudtam, hogy szükségem lesz az este folyamán kész- 
pénzre, s nagyon megörültem, mikor a buszmegállóval szemben volt a bankom egyik ATM-je, így könnyen és gyorsan készpénzhez juthattam." (nó, 24 év)

Ezenkívül azonban említettek még telefonos parkolódíj-befizetést, s ételrendelést is.

\section{Jobb, mint az alternativa}

Az elégedettséget kiváltó kritikus esetek többsége azon okra vezethetố vissza, hogy az önkiszolgáló technológia nyújtotta szolgáltatás jobb választásnak bizonyult, mint a hagyományos szolgáltatási csatorna. Mivel az önkiszolgálás számos elônnyel rendelkezik a személyes csatornával szemben, több alpontot is meg lehet különböztetni e kategórián belül.

\section{Könnyebb a szolgáltatás igénybevétele}

Ezen eseteknél elsôsorban az önkiszolgáló technológia azon elônyeiról szóltak az elbeszélések, melyben az önkiszolgáló szolgáltatási mód valamely okból megkönnyítette számukra a szolgáltatás igénybevételét. A beszámolók szerint a könnyebb, egyszerúbb használat magas fokú elégedettséghez vezet. Példaként említenénk az on-line adatmódosításokat és vásárlásokat. Ez utóbbiak a fogyasztók szerint sokkal kényelmesebbé és egyszerúbbé válnak a könnyú összehasonlíthatóság miatt. Ezen belül is gyakori példa volt a múszaki cikkek (mobiltelefonok, laptopok) on-line vásárlása.

„Januárban új mobiltelefont szerettem volna vásárolni, de a boltok kínálata mindig csak összezavart. Az interneten csak beírtam a számomra megfelelö koordinátákat, és könnyen össze tudtam hasonlítani a kilistázott termékeket. Azután meg egyszerüen meg is tudtam rendelni a honlapon." (férfi, 26 év)

Az idézetból kitûnik, hogy mind az informálódás, mind a tranzakció elvégzése külön-külön is lehet az elégedettség forrása. Különösen fontos forrásává vált az internet az árinformációk összegyújtésének és a termékinformációk strukturált keresésének.

\section{Nincs személyes kapcsolat}

A megkérdezettek között egyeseknél az elégedettséget kimondottan a szolgáltató személyzet hiánya okozta, mert elmondásaik alapján nem szeretnek interakcióba lépni az eladókkal. A válaszadók között akadtak olyanok, akik számára kellemetlenséget jelent beszélgetni a szolgáltató személyzettel, mások pedig korábbi rossz tapasztalatok miatt kerülik a személyes interakciót. Voltak, akik úgy gondolták, sokkal hatékonyabb a szolgáltatás elvégzése, ha maguk viszik véghez. Egyik megkérdezett pedig úgy érezte, a saját személyiségéhez jobban illik az önkiszolgáló technológia használata:
„Tudom, nem vagyok egyszerü eset, ezért (finoman szólva) többször is kerültem már összetüzésbe ügyintézókkel. Az internetes bankolással és ügyintézéssel mindketten jobban járunk: a szolgáltató és én is.” (nó, 28 év)

Ez az idézet egy új dimenziót vet fel, a fogyasztó személyiségéhez való illeszkedés szempontját. Amenynyiben a fogyasztó úgy ítéli meg, hogy az adott technológia illeszkedik egyéniségéhez, akkor szívesen kipróbálja és használja.

\section{Idómegtakarítás}

Ennél a csoportnál a legfő́bb elônyt az jelentette, hogy kevesebb idóbe telik a szolgáltatás elvégzése, mintha a hagyományos, személyes módon történne. Az időmegtakarítás alatt voltak, akik a sorban állás, az utazás idejének megtakarítását említették, míg mások arról is beszámoltak, hogy az ügyintézés is gyorsabb lehet, ha maguk végzik, mintha arra várnának, hogy az alkalmazott elvégezze a feladatot. Itt fóként az on-line bankolás lehetôségét, s a számlabefizetéseket említették a válaszadók.

Az idôtényező fontos szerephez jut az önkiszolgáló technológiáknál. Azonban nemcsak pozitív módon, hanem sokszor éppen ellentétesen, negatívan érzékelik a fogyasztók e szempontot. Amikor az önkiszolgálás nem úgy múködik, ahogy a fogyasztó elképzelte, akkor sokszor idôigényesebb, mint a személyes alternatíva. Ez rámutat a szerepelmélet késóbbiekben tárgyalt fontosságára, hiszen hogyha nincs jól kialakult forgatókönyv a fogyasztó fejében, esetleg hibás, akkor fordulhat elő a negatív helyzet.

\section{Amikor és ahol akarom}

A megkérdezettek elmondása szerint a rendkívüli elégedettséget kiváltó okok egyike, hogy az önkiszolgáló szolgáltatás a hagyományossal szemben szinte bármikor és bárhol elérhetố. Az interjúk alapján elmondhatjuk, hogy meglehetősen vonzó a fogyasztók számára, hogy a hagyományos csatornák nyitvatartási óráin túl is képesek a szolgáltatást igénybe venni. Sok példa jelent meg ebben a kategóriában, említhetô az internetes vásárlások számos fajtája, de volt, akinek egy ételrendelés okozott kiemelkedően pozitív élményt:

„A szilveszteri házibuliban már éffél elótt elfogyott az étel, azonban az interneten szerencsére találtunk olyan pizzaszállitót, aki nagy mennyiségben is tudott kiszállítani, ráadásul 1 órán belül, ezzel szinte megmentve a bulit." (férfi, 24 év)

Az elônyök felsorolásánál gyakran megjelent az „otthonról végezhetô" kifejezés, s ezt az elmondott történetek is alátámasztották. Többen említették példaként, hogy külföldi tartózkodásuk alatt is tudták az itthoni ügyeiket intézni interneten keresztül. 


\section{Pénzmegtakarítás}

Az elmondott esetek között akadtak olyanok, melyekben a pénzmegtakarítás vezetett kiemelkedô elégedettséghez a fogyasztó számára. Itt az önkiszolgáló szolgáltatás igénybevétele sokkal olcsóbban történik, mint a hagyományos csatornákon. Említettek például interneten történố utalást, vagy akár biztosításkötést is.

„Négy gyermeket nevelek, akik közül kettó tinédzser korú, így gyakran kérnek tólem pénzt. A folyamatos készpénzfelvétel egy idô után komoly költségekkel járt. Miután megtanultam az on-line átutalást, és bankkártyájukra utalom a zsebpénzüket, már az elsó hónapban szemmel láthatóvá vált a számlámon az így megtakarított pénz." (nô, 54 év)

Ennél a szempontnál is meg kell azonban jegyeznünk, hogy a pénzmegtakarítás is csak abban az esetben múködhet, ha a fogyasztó tisztában van a múködés elveivel, és megfelelóen tudja használni a technológiát. Abban az esetben, ha ez nem így van, gyakran éppen ellenkezóképpen, plusz kiadáshoz vezet a nem megfelelő múködés/alkalmazás. A következô idézet erre utal.

„Véletlenül három színházjegyet vettem, pedig kettốt akartam." (nő, 23 év)

\section{Megfelelóen múködött}

A rendkívüli elégedettség oka néha nem más, minthogy az önkiszolgáló rendszer megfelelóen múködik. Ilyenkor egyszerúen és gyorsan el tudták végezni a fogyasztók a szolgáltatást, és sokszor ez meglepetésként érte óket, melyre szívesen emlékeznek vissza. Volt, aki kuponos oldalakon vásárolt szolgáltatást említett, azonban az egyszerú színházjegyvétel is példaként említhetô. Ezenkívül volt, akinek kétségei voltak az elsố nagyobb értékú internetes vásárlásakor, ezért már az is kiemelkedően pozitív élményt jelentett számára, mikor a viszonylag nagy értékú laptop egy másik kontinensról, idôben, sértetlenül megérkezett.

„Nem vagyok az a parázós fajta, de amikor Amerikából rendeltem akciósan Macbookot, volt egy-két álmatlan éjszakám. De annál nagyobb volt az öröm, mikor meghozták idóre, tök korrekt dobozban, pöpecül." (férfi, 25 év)

\section{Hiba során gyors javítás}

Ahogy az elméleti részben rámutattunk, nehéz egy technológiánál teljes mértékben kiszúrni a hibapontokat, ám a hiba keletkezésekor a gyors hibaelhárítás és segítség szintén kellemes élményként maradhat meg a fogyasztóban. Így a válaszadások alapján úgy túnik, a szakmailag megfelelő és fogyasztóbarát hibaelhárítás szintén elégedettséghez vezethet.
„On-line nyelvvizsga-jelentkezéskor elutaltam az összeget, de napokig nem kaptam visszajelzést a jelentkezés aktiválásáról. Mikor telefonon felhívtam óket utánanéztek és elnézést kértek a késedelmes visszajelzésért. Nagyon kedvesek voltak, rögtön meg is nyugodtam." (nő, 22 év)

Amint azt a következó részben látni fogjuk, ennek éppen az ellenkezôje is megtörténhet, ez éppen a különös elégedetlenség forrása lesz.

\section{Elégedetlenségre okot adó tényezôk}

\section{Technológiai hiba}

Az elégedetlenséggel kapcsolatos esetek nagy részénél a negatív élmény előidézóje a technológiai meghibásodás volt. Az önkiszolgáló rendszerek technológiaalapú mivolta miatt a rendszer hibája gyakran okozhat fogyasztói elégedetlenséget. Az elmondások alapján a technológia sokszor nem tudta a megfelelő szolgáltatást nyújtani, gyakoriak voltak ezen belül is az ATM-mel kapcsolatos példák.

„,Fizetés után szerettem volna egy nagyobb összeget felvenni, azonban megállt a szívem, mikor megláttam a kiadott húszezreseket. Mindnek le volt vágva a jobb alsó sarka, mintha pengével tették volna." (nő, 52 év)

Fớként azon problémáknál lehetett rendkívüli elégedetlenséget érzékelni, mikor a fogyasztónak sürgôs esetekben kellett használnia az önkiszolgáló technológiákat, vagy amikor a hagyományos csatornák már nem voltak elérhetók. Ilyenkor nem tudott más opciót választani a hibás teljesítéskor, ami növelte az elégedetlenségüket. A megkérdezettek hozzátették, hogy tisztában vannak azzal, hogy a technológia olykor meghibásodik, mégis negatív élményként maradtak meg számukra a felvázolt esetek.

\section{Folyamathiba}

Ennél a hibatípusnál a fogyasztó számára a problémát nem a technológiai meghibásodás jelentette, hanem a teljesítés során fordult elő kellemetlenség. Ezek kapcsolódtak kiszállításhoz, teljesítéshez, számlázáshoz egyaránt.

„Éppen a határidố elótti napon jelentkeztem egy nyelvvizsgára on-line, amit banki átutalással fizettem ki. Azonban a pénz nem érkezett meg a következó munkanapon a számlára, így késési pótdijat kellett befizetnem, ami nagyon felháborított." (nó, 24 év)

Ezen csoport tagjai fogadták el a hibát legnehezebben, elsősorban azért, mert nem tudták azonosítani a hiba okát és azt, hogy kihez lehet fordulni ilyen esetekben. 


\section{Designprobléma}

Az önkiszolgáló technológiák hiányosan vagy roszszul megtervezett kivitelezése is gyakori oka volt a fogyasztók elégedetlenségének. Ezen belül is két kategóriát lehet megkülönböztetni: a technológiai és a szolgáltatásdesign okozta problémát.

\section{Technológiai design}

Ezen eseteknél az önkiszolgáló rendszer múködőképes, valamint a teljesítés gond nélkül végbemegy, azonban akadnak olyan pontok a rendszer kialakításában, melyeknél nehézségbe ütközik a fogyasztó. Beszámoltak például túl bonyolult weboldalakról, nem megfelelóen feltüntetett szolgáltatási lehetôségekról is.

„Bécsbe foglaltam koncertjegyet, de olyan bonyolult volt az oldal, hogy alig tudtam egyet lefoglalni. Mikor már kifizettem, utána tudtam meg, hogy lehetett volna diákjegyet igényelnem olcsóbban, de erról nem tájékoztatott a rendszer." (nó, 23 év)

A nehezen használható vagy rosszul átlátható weblap-kialakítás akár pénzügyi veszteséghez is vezethet, de mindenképpen felesleges időveszteséget okoz a fogyasztó számára.

„A Ryanair honlapján foglaltam repülójegyet, mikor az utolsó lépésnél kiderült, hogy nem minden fajta bankkártyával olyan olcsó, így az én OTP-semmel másfélszer annyit fizettem. Szólhattak volna az elején is." (férfi, 28 év)

\section{Szolgáltatásdesign}

Ezen eseteknél az önkiszolgáló felület kialakítása megfeleló, azonban maga a szolgáltatás folyamatának kivitelezése nem kedvezô. Ez a fogyasztó számára ismét csak elvezet a pénzügyi veszteséghez. Akadt olyan is, akinél a folyamat módja okozott elégedetlenséget.

„A ticketmaster.de-n történó jegyvásárlás után postán küldték ki a jegyet, annak ellenére, hogy ma már mindenki elektronikus jegyet használ. Napokig aggódtam, hogy nem lesz jegyem, felhívni nem akartam óket a magas percdíjak miatt." (nô, 25 év)

\section{Fogyasztói hibázás}

A megkérdezettek között akadtak ugyan olyanok, akik tudták, hogy saját hibájukból adódóan lépett fel komplikáció a szolgáltatás teljesülése során, mégis nagyon elégedetlenek voltak a hibás szolgáltatással. Többször elófordult ezen eseteknél a felhasználónév vagy PIN-kód elfelejtése, hibás megadása.

„Összekevertem a magyar és az amerikai bankkártyám PIN-kódját, és egyik pénteken kint a magyar kártyámat emiatt elnyelte az ATM. Az amerikai kártyámra még nem érkezett meg a nyári fizetésem, így hétfóig szó szerint éheznem kellett New Yorkban, mert nem maradt nálam pénz vagy használható kártya." (nő, 22 év)

Ezen esetekben a fogyasztó - bár tudja, hogy ô maga hibázott - mégis elvárná, hogy a szolgáltató adjon valamilyen megoldási lehetôséget a hibahelyzet kezelésére. Sok esetben ilyenkor a tehetetlenség érzése jelentôs negatív fogyasztói emóciót vált ki.

\section{Nincs más alternativa}

A megkérdezettek között - különösen a szenior korosztály tagjainál - elófordult, hogy az elégedetlenséget okozó tényezốt az jelentette, hogy a fogyasztónak nincs lehetősége választani a hagyományos és az önkiszolgáló technológia között, s ebből valamilyen fajta negatív élménye keletkezett. Az egyik konkrét eset egy repülőjegy vásárlásánál történt:

„A lányom külföldön kórházba került, és utána szerettem volna menni, mert nagyon aggódtam. Viszont nem tudtam, hogy kell a netes repülójegyeket megvenni, az utazási irodákban pedig csak drágák voltak. Több órát töltöttem a foglalással, végül pedig a szomszédtól kellett segitséget kérnem, akivel ráadásul nem is vagyok jóban. Rendkivül kellemetlen helyzet volt." (nő, 58 év)

Ezekben az esetekben a fogyasztó kényszerítve érzi magát az önkiszolgálás elvégzésére, ami jelentős negatív érzést vált ki, különösen, ha nem érzi magát elég magabiztosnak és képzettnek az önkiszolgáló technológia alkalmazására.

\section{Segítố személyzet viselkedése}

A negatív élmények felsorolásában külön csoportot alkottak azon esetek, melyeknél az önkiszolgáló rendszerrel kapcsolatos segító személyzet viselkedése okozta az elégedetlenséget. Gyakori volt a telefonos vevôszolgálat dolgozóinak példája, akik nem megfelelố hangnemben beszéltek, vagy nem voltak kompetensek az esetleges hiba elhárításában. Akadt azonban olyan eset is, melyben az önkiszolgáló rendszert oktató személyzet maga sem tudta, hogyan kell pontosan használni a technológiát. Az áruházakban lévő kasszák többször ismétlődoó példák voltak, nemcsak pozitív, hanem negatív értelemben is.

„Péntek este nagy volt a sor a kasszáknál, és az alkalmazottak mindenáron az önkiszolgáló kasszához akarták a vevóket terelni. Már az is kellemetlen volt, hogy szinte erốszakkal kellett ezt a formát választanom, de ezt csak tetózte, mikor az ott álló hölgy sem tudta lehúzni az árut. Perceket vesztegeltünk, próbálgatva azt a leolvasó izét, mire megelégeltem, és visszaálltam a hagyományos sorba, persze a végére. Rendkivül ideges lettem, mire végeztem a bevásárlással." (nő, 58 év) 
Összességében az önkiszolgáló rendszerek típusait vizsgálva elmondható, hogy a telefonalapú önkiszolgáló rendszerrel voltak a legelégedetlenebbek a válaszadók. Legtöbbször túl bonyolultnak tartják átláthatatlan lépésekkel, túl sok információt kérnek a fogyasztótól, melyeknek az nincs mindig tudatában. Ezt követôen a kioszkoknál jelentkező problémák a leggyakoribbak, ott is legtöbbször a pénzfelvétellel kapcsolatos technológiai hibák jelentek meg. Végül, de nem utolsósorban, az interneten történó ügyintézéssel kapcsolatos problémák jelennek meg, ezen belül is a repülőjegyvétellel, vásárlásokkal, on-line ügyintézéssel kapcsolatosan.

\section{Az elégedettséget és elégedetlenséget befolyásoló legfontosabb fogyasztóhoz köthetố tényezók}

Az elóbbiekben bemutatott csoportosítás alapját a fogyasztók számára érzékelt előnyök vagy hátrányok jelentették (Meuter et al., 2000). Ez a tipológia azonban nem foglalkozik azokkal a tényezókkel, amelyek akár a fogyasztóhoz kötődôen, akár a technológiához kötódốn befolyásolhatják a fogyasztói elégedettséget. Erre vonatkozóan az elsố részben bemutatott szakirodalmi összefoglaló ad egyfajta iránymutatást, cikkünkben elsősorban azokat a tényezóket kívánjuk összefoglalni, amelyek az általunk megkérdezett fogyasztók számára váltak kritikussá, s a kutatásokban mind ez idáig nem kaptak hangsúlyos szerepet.

Az interjúk alapján jelentôs tényezőnek túnik az élmény szerepe. A fogyasztók számára sok esetben az önkiszolgálás élményszerúsége jelent vonzerôt. Bartl et al. 2013-as kutatásukban a vevői elragadtatás érzését (customer delight) kísérelték meg az önkiszolgáló technológiák kapcsán vizsgálni, amely mindenképpen egy lépés az élményszerúség forrásainak feltárásában. Interjúalanyaink közül többen említettek olyan eseteket, melyben az önkiszolgáló rendszer használata maradandó élményként ragadt meg bennük, ezáltal növelve elégedettségüket. Többen említették itt a Magyarországon pár éve múködő önkiszolgáló pénztárakat.

„Kiskoromban pénztáros szerettem volna lenni, ezért nagy örömöt okozott, mikor végre magamnak húzhattam le a vásárolt termékeket. Így legalább a saját magam pénztárosa lehetek néha!" (nő, 55 év)

Ez az idézet egy következő szempontra is rámutat: a fogyasztó kezében lévố kontroll különös elégedettséggel töltheti el. Mind az elégedettség, mind az elégedetlenség sokszor a kontroll meglétéból vagy hiányából fakad. Az elégedetlenség esetében különösen fontos faktor, hogy a fogyasztó úgy érzi, kicsúszott a kezéboól az irányítás, a gép átveszi a szerepét, és esz- köztelen vele szemben. Ezekben az esetekben jelentôs igény mutatkozott meg a szolgáltatóval történő azonnali személyes kapcsolt kialakításának lehetőségére. Ez az eredmény összhangban van Wünderlich et al. 2013-ban közölt kutatásával, amelyben a fogyasztó számára megélt kontroll fontosságára hívták fel a figyelmet, amely sok esetben az élố személlyel való interakciót jelenti.

Egy másik tényező, amelynek hatása egy új szempontot vet fel, a szerepegyezóség. Többször elhangzott az interjúkban, hogy az elégedettség forrása az, hogy a technológia éppen az én személyiségemhez való, illetve olyanná tesz, amilyennek látni szeretném magamat (pl. fiatalabbá).

„Hát az a jó benne, hogy fiatalabbnak érzem magam, mikor használom." (nô, 56 év)

Ezt a tényezőt tudomásunk szerint az önkiszolgáló technológiák kutatása során még nem vizsgálták.

A személyes kontaktus igénye több kutatásban is elöfordul, de elsősorban, mint olyan tényező, amely akadályozza az elfogadást. A hagyományos gondolatmenet szerint a fogyasztók alapvetóen értékesnek tartják a szolgáltatókkal való személyes kontaktust (Bateson, 1985; Dabholkar, 2000; Zeithaml - Gilly, 1987; Curran - Meuter, 2007). Kutatási eredményeink érdekessége, hogy a személyes kontaktusnak nemcsak az igénye, de a kerülése is lényeges szempont a használat során. Vannak olyan fogyasztók, akik kifejezetten kerülik a személyes kontaktust a szolgáltatóval. Ez eredményeink szerint inkább a fiatalokra volt jellemzô.

Kiemelnénk még egy tényezót, amelynek szerepe a folyamatos használatra van nagy hatással. Ez a tényezố az elsố találkozás élménye az adott önkiszolgáló technológiával. Kiemelkedôen fontosnak tűnik az interjúk alapján az elsố tapasztalat szerepe abban, hogy rendszeres használóvá válik-e a fogyasztó. A kutatások elsốsorban a kipróbálásra teszik a hangsúlyt - ami valóban szükséges a használathoz -, de kevéssé foglalkoznak azzal, hogy mi történik késóbb, az elfogadás további szakaszaiban. Hogyan lehet például az elsô negatív élményt pozitívvá tenni, illetve mit kell tenni ezekkel a negatív élményekkel (amelyek akadályozzák a rendszeres használóvá válást)?

A gyakrabban elókerülő tényezók között szerepelt az alternatívák közötti választás lehetốsége. Azokat az eseteket, amikor a fogyasztóknak nem kínáltak fel alternatívát, hanem az önkiszolgálás volt az egyetlen lehetôség, sokszor negatívan élték meg, és elégedetlenséghez vezetett. A témában történt újabb kutatások is kimutatták (Liu, 2012), hogy a kényszerített használat erôteljesen csökkenti az elégedettséget, és ezen keresztuil a használatot. 


\section{Forgatókönyv-elmélet}

Mivel az önkiszolgáló rendszerek használatánál magasabb fokú fogyasztói részvétel indokolt, megvizsgáltuk, hogy mennyire vannak tisztában a fogyasztók saját szerepeikkel, honnan tájékozódnak, és mennyire befolyásolja ốket mindez a szolgáltatás során.

Összességében a két korcsoport között radikális eltérést e témakörben nem találtunk. Az interjúkat elemezve általánosságban elmondható, hogy a fogyasztók elsô találkozása az adott önkiszolgáló rendszerrel meghatározó jelentôségú. Eredményeink alapján a megkérdezettek a forgatókönyv létezése s annak tartalma szerint három csoportba sorolhatók.

\section{Létezik biztos szkript, s ez nagyrészt megegyezik a valós folyamattal}

Ezeknél az eseteknél a fogyasztók fejében létezik egy forgatókönyv az önkiszolgáló rendszer használatáról, s ez alapján használják azt az adott helyzetben. Ilyenkor a folyamat, s annak lépései nagyrészt megegyeznek az elózetesen elképzeltekkel, s ennek köszönhetóen a használat zökkenőmentesen, gyorsan történik. A fogyasztó ezáltal minden esetben elégedettnek vallotta magát:

„Nagyon egyszerú volt a vásárlás, úgy ment, mint a többi on-line vásárló oldalon." (nô, 54 év)

A szkript kialakításában több előzetes forrás is segíthet. Egyrészt kiemelnénk a megkérdezettek által említett megfigyeléseket.

„Egyszer megnéztem, a lányom hogyan rendel a kuponos oldalról, utána már könnyen ment nekem is." (nô, 52 év)

Ugyanígy a szkript kialakítására adnak lehetôséget az interneten megjelenó információk is.

„Ha valamit nem tudok, megnézem a neten, ott minden fent van." (nó, 22 év)

Voltak, akik egyéb helyekról informálódtak:

„Az M1-en megy egy tévémúsor, amiben szépen elmondják, hogy kell netezni, onnan tanultam meg a regisztrációkat is." (nô, 56 év)

A használat során magabiztosnak vallották magukat, és sok esetben jelentett ilyenkor élményt az önkiszolgálás számukra, s realizálni tudták az önkiszolgáló rendszer előnyeit. A használatuk ezáltal elégedettséget idézett elő, szívesen ismételik meg a használatot, rendszeresítik életükben. Elmondásuk alapján a bonyolultság észlelése is csökken ezen esetekben:

„Ha tudja az ember, mit kell tenni, egyáltalán nem bonyolult a dolog." (nő, 22 év)

A csoportra jellemző, hogy szívesen használják újra a már begyakorolt, jól múködő technológiát, hiszen minden alkalommal már tisztában vannak a lépések- kel, idôráfordítással. Ezenkívül szívesen osztják meg pozitív élményeiket, adják tovább tudásukat a még „tudatlan” fogyasztóknak, ismerősöknek, barátoknak. Mindez serkenti ôket a további önkiszolgáló rendszerek megismerésére s kipróbálására.

Létezik szkript, azonban nincs biztos alapja, s csak részben fedi a valóságot

A megkérdezettek többször említettek olyan esetet, mikor az önkiszolgáló rendszer használatánál csak sejtéseik léteztek. Ezek a forgatókönyvek legtöbbször internal típusúak voltak, azaz a fogyasztó fejében fogantak meg, nem külsô tanulás eredményeként.

Mivel a szkriptekben nem voltak teljesen biztosak, így a magabiztosságuk is alacsony volt a használat során.

„Nem tudtam, hogy hogyan kell színházjegyet foglalni, ezért minden lépésnél megálltam körülnézni egy kicsit, minden oké-e." (nő, 56 év)

A használat ezen esetekben többkimenetelú volt. Voltak megkérdezettek, akik ilyenkor is sikeresnek érezték magukat.

„Csak azt tudtam, hogyan kell belépni, de aztán addig olvasgattam, ameddig rá nem jöttem, hogy tudok utalni." (férfi, 55 év)

Az idézetból is látható, hogy kiemelten fontos a használat során történó informálás. Ha a szolgáltatásigénybevétel elején és során információval látják el a fogyasztókat a saját szerepükról és a folyamat menetéről, akkor tisztábban látják a saját feladatukat, s a használat is elégedettséggel zárul. Fớként a magabiztos személyiséggel rendelkező, kitartó fogyasztókra jellemző, hogy sokáig próbálkoznak annak ellenére, hogy nincsenek tisztában, hogyan zajlik a szolgáltatás.

Azok azonban, akik csak rossz minóségú szkripttel kezdtek neki az önkiszolgáló rendszer használatának, gyakran sikertelenséggel zárták.

„Nem tudtam, hogy megy ez az on-line felvételi jelentkezés, csak jónak tünt. De olyan bonyolult volt az egész, egy csomó mindent nem értettem, így inkább sorban álltam vele a postán." (nő, 20 év)

Ebben a csoportban jelent meg többször az elégedetlenség okaként, hogy a fogyasztó biztosnak vélt szkripttel kezdett neki a folyamatnak, azonban egy adott ponton eltérést tapasztalt, s ez zavart okozott a használat során. Itt említettek hasonló szolgáltatással rendelkező, de más kialakítású portálokat (kuponos oldalak), de felmerültek olyan esetek, mikor külföldön egyes önkiszolgáló rendszerek máshogy néztek ki, mit a megszokott.

„Németországban szerettem volna pénzt kivenni, de nem tudtam sem angolul, sem németül. A gombok is máshogy voltak, mint amiket itthon megszoktam, nagyon megijedtem, hogy mi lesz." (nő, 52 év) 
Ha tehát a fogyasztó fejében lévő szkript eltér a megszokottól, gyakran abbahagyja a rendszer használatát. Az ilyen esetek többségénél a fogyasztók egy késóbbi alkalommal még megkísérlik újra használni a technológiát, azonban két sikertelen alkalom után volt, hogy visszatértek a hagyományos szolgáltatás igénybevételéhez.

\section{Nem létezik szkript}

A megkérdezettek olyan esetekról is beszámoltak, ahol nem voltak magabiztosak az önkiszolgáló rendszer használatában. Ilyenkor legtöbbször nem mernek önmaguk hozzákezdeni az önkiszolgáláshoz. Ha mégis, a használat oka nagyrészt a szükséghelyzet (internetes repülőjegyvétel, internetes ételrendelés), bár volt, aki puszta kíváncsiságból vágott neki az ,ismeretlennek”.

Ezen esetek többsége azonban egyértelmúen negatív kimenettel végzódött. A fogyasztó vagy abbahagyta a használatot, vagy nem megfelelő eredménnyel vette igénybe a rendszert.

„Olyan bonyolult volt a westendes térkép, hogy inkább megkerestem magam az üzletet." (nó, 50 év)

Az elmondások alapján, a rossz tapasztalatok után nem szívesen használják újra az adott önkiszolgáló technológiát. Akik használják, azok is csak hosszú idő elteltével, s előtte tájékozódnak a használati lépésekról. Azonban a korábbi, negatív élmény miatt a tanulás is nehezebb számukra.

Ezeknél az eseteknél tehát a fogyasztó nincs tisztában a saját szerepével, a folyamat lépéseivel, így a használati idő is hosszabb, s a rendszert bonyolultabbnak ítélik. A magabiztosság hiánya miatt pedig sokszor a sikeres használat sem pozitív élményként marad meg a fogyasztóban.

„Végül megoldották a problémámat, de többször nekifutottam, összevissza nyomogattam a gombokat." (ffi, 28 év)

Hozzá kell tenni, hogy egy-két esetben ilyenkor is volt, amikor pozitív élménnyel zárult az önkiszolgálás. A kitartóbbak többször nekifutnak, mindaddig, amíg nem sikerül véghezvinniük a folyamatot. Ezekben az esetekben azonban közös pont, hogy a szolgáltatás különösen fontos a fogyasztónak.

„Addig próbálkoztam, amíg nem sikerült megvennem a kupont, mert nagyon rég ki akartam próbálni azt a kúrát, de alapáron nem tudtam volna megfizetni." (nô, 58 év)

Az önkiszolgáló rendszerek típusait végignézve elmondható, hogy különbözó mértékben létezik szkript a fogyasztók fejében. A válaszadók legbonyolultabbnak a telefonalapú önkiszolgáló rendszert tartották. Az elmondások alapján ezen esetek többségében a fogyasztók nincsenek tisztában a lépésekkel, s nehezen tájékozód- nak a használat közben is. A menü használata rendkívül bonyolultnak túnik számukra, s a forgatókönyv hiánya miatt nem tudják, jól használják-e, gyakran félbehagyják a használatot, s ez mindkét korosztályra igaz volt. A telefonos menürendszerek kiismerhetetlenségéhez hozzájárul, hogy a legtöbb szolgáltató saját, egyéni rendszert használ, s még ha van is a fogyasztó fejében egy jól kialakult szkript az egyik rendszer alapján, ezt a másik esetben már nem tudja fölhasználni.

$\mathrm{Az}$ internet kissé megosztotta a megkérdezetteket, elsősorban az interneten fellelhetô önkiszolgáló rendszerek rendkívül magas száma és változó típusa miatt. A fiatalok legtöbbször egyszerúbb és pontosabb szkriptet vázoltak fel maguknak az internetes önkiszolgálás során. Az idôsebb megkérdezettek sok esetben a regisztrációt követően nem rendelkeznek forgatókönyvvel a folyamatról, így a vásárlások, s néha az on-line bankolás is problémát jelent számukra. A fizetés feltételeirôl aggodalmukat fejezték ki, nem mindig tudják pontosan, hogyan használják a bankkártyájukat, $\mathrm{s}$ az adatvédelmet tekintve is félelem van bennük. A használat ideje ezáltal megnő, hiszen nem tudják, mi a feladataik pontos sorrendje, gyakran összezavarodnak, s félbehagyják a használatot.

A kioszkokban mindkét csoport válaszadói bátrabban vágnak bele az önkiszolgálásba. A használatot megkönnyíti a megfigyelhetôség, hiszen elmondásuk szerint mielőtt használatba veszik, lehetőség van rá, hogy végignézzék, más fogyasztók hogyan használják a rendszert. Ezáltal kapnak egy alaptudást a szerepükról, s a folyamat lépései sem számítanak számukra ismeretlennek. Kiemelnénk még a kioszkoknál a segítô személyzet szerepét. A személyzet jelenlétét a fogyasztók pozitívan értékelik, s szívesen fogadják a segítséget. Többször panaszkodtak azonban arra, hogy a segítség nyújtása nem megfelelố módon történik. A fogyasztók negatívan értékelik azt a típusú segítséget, amikor a személyzet elvégzi helyettük az önkiszolgálást. Ezen esetekben a fogyasztó nem azt várja el a segítótól, hogy elvégezze a feladatot, hanem hogy megtanítsa a használatot. Probléma merült fel a nem kompetens, valamint a nem megfelelő modorral rendelkezô munkatársakkal kapcsolatban is.

A korosztálybeli különbséget tekintve úgy túnik, hogy a fiatalok hajlamosabbak szkript létezése nélkül is kipróbálni az önkiszolgálást, azonban az idősebbek kitartóbbnak bizonyulnak a negatív tapasztalatok után is. A fogyasztók az összes technológiát tekintve úgy nyilatkoztak, hogy szívesen tanulnának a használatról. Az edukáció folyamatáról azonban már eltéróek voltak a vélemények. A fiatalabb korosztály inkább a folyamat során akár a helyszínen, akár a weboldalon tájé- 
kozódik. A szenior korosztály szereti elôre biztosítani magát, s a használat előtt néz utána az ilyen rendszerek használatának.

Közös volt azonban az igény, miszerint megkönynyíti számukra a használatot, ha már az elején tisztában vannak a lépésekkel, s a folyamat során látják, hol tartanak a szolgáltatás igénybevételének fázisában, s mit kell még tenniük.

\section{Összegzés}

A kutatásunkat összefoglalva általánosságban elmondható, hogy a fogyasztók ismerik és szívesen használják az önkiszolgáló rendszereket a mindennapjaik során.

A megkérdezés alapján sem használatbeli, sem szerepelmélettel kapcsolatos, releváns eltérés nem mutatkozott az idősebb és fiatalabb megkérdezettek közt. Az interjúkra támaszkodva arra következtethetünk, hogy a kor nem meghatározó befolyásoló faktor. Ezt a feltételezést azonban mindenképpen ellenórizni szükséges kvantitatív módszerekkel Az interjúk alapján elmondhatjuk, hogy a használatban az önkiszolgáló technológiák típusát és gyakoriságát sokkal inkább különböző személyiségjellemzók határozzák meg, mint például az újdonságkeresés iránti vágy, vagy a személyes interakció igénye.

Összességében elmondható, hogy léteznek szkriptek a fogyasztók fejében, s ezek, az interjúk alapján, igenis befolyásolják a fogyasztókat. Döntô jelentôségú az elsô alkalom, hiszen az elsô találkozáskor bekövetkezô használat meghatározhatja a fogyasztó további kapcsolatát az adott önkiszolgáló technológiával.

Az elemzett kritikus esetek domináns többségénél az elégedettség és az elégedetlenség közvetlenül vagy közvetve összefüggésbe hozható a forgatókönyv-elmélettel. Ennek alapján az elégedettséget okozó eseteknél azt tapasztaltuk, hogy akkor tudják a fogyasztók realizálni az önkiszolgáló rendszerek nyújtotta előnyöket, ha ismerik szerepüket a folyamat során, s így a szolgáltatásnyújtás zökkenőmentesen mehet végbe. Az elégedetlenség okát pedig sokszor a nem tiszta forgatókönyv jelentette, melyból kifolyólag a fogyasztó bonyolultnak vélte a technológiát, esetleg nem megfelelő lett a szolgáltatás végeredménye, esetleg idốt és pénzt veszített általa.

A forgatókönyvek megléte és egyezősége tehát segíti a folyamatot, míg a szkriptek hiánya gyakran vezet elégedetlenséghez. Fontos ezáltal a fogyasztói edukáció, hiszen a tudással magabiztosabbá válnak, s a használatuk is strukturáltabb lesz. Az edukáció érvényes mind az igénybevétel előtti, mind az igénybevétel során fellépó feladatokra. A fogyasztók magabiztosabbak, ha már használat előtt tudatában vannak a szerepüknek, azonban a folyamat során is szeretik látni a lépéseket, $\mathrm{s}$ azt, hol tartanak éppen a folyamatban. Az elégedettség továbbá hozzásegít ahhoz, hogy újabb rendszereket próbáljanak ki, s szájreklámmal segítsék elô az önkiszolgáló rendszerek használatának terjedését.

Ha a használó megtanulja a saját szerepét, s biztos forgatókönyvvel veszi igénybe az önkiszolgáló rendszereket, megszabadul a hibás igénybevétel félelmétốl. A szereptisztaság tehát hozzájárul a sikeres igénybevételhez, ami mind a fogyasztó, mind a szolgáltató számára fontos. Érdemes tehát a szolgáltatóknak ezzel a témakörrel foglalkozniuk, s felmérniük a használók tudását, $\mathrm{s}$ ahhoz mérten kialakítaniuk a rendszereket, az informálás módját, mértékét s helyét.

Jövốbeli kutatási kérdésként érdekesnek találjuk a szerepelmélet és a fogyasztói részvétel, a közös értékteremtés koncepciójának összevetését, és annak vizsgálatát, hogy az önkiszolgáló technológia használója milyen módon tud kötődni a technológia alakításához. Ehhez szükséges a szerepek tisztázása, és annak tudatosítása a fogyasztóban, hogy a technológia nem tôle függetlenül múködik, hanem szerves része a vevối értékteremtésnek.

\section{Felhasznált irodalom}

Ajzen, I. - Fishbein, M. (1980): Understanding Attitudes and Predicting Social Behavior. Englewood Cliffs, NJ: Prentice Hall

Bartl, C.M. - Gouthier, H.J. - Lenker, M. (2013): Delighting Consumers Click by Click: Antecedents and Effects of Delight Online. Journal of Services Research, Vol. 16 (3): p. 386-399.

Bateson, J. (2002a): Customer performance and quality in services. Managing Service Quality, 12 (4): p. 206-209.

Bateson, J. (2002b): Are your customers good enough for your service business?, Academy of Management Executive, Vol. 16 (4): p. 110-120.

Bitner, M.J. - Booms, B.H. - Tetreault, M.S. (1990): The Service Encounter: Diagnosing Favourable and Unfavourable Incidents. Journal of Marketing, 54 (January): p. 71-84.

Bitner, M.J. - Brown, S.W. - Meuter, M.L. (2000): Technology Infusion in Service Encounters. Journal of the Academy of Marketing Science, 28 (1): p. 138-149.

Bitner, M.J. - Farada, W.T. - Hubbert, A.R. - Zeithaml, V.A. (1997): Customers' contributions and role in service delivery. International Journal of Service Industry Management, Vol. 8 (3): p. 193-205.

Bitner, M.J. - Ostrom, A. - Meuter, M. (2002): Implementing Successful Self-Service Technologies. Academy of Management Executive, 16 (4): p. 96-108.

Bozinoff, L - Roth, V.J. (1983): Recognition memory for script activities: an energy conservation application. 
Advances in Consumer Research X: p. 655-660. Thirteenth Annual Conference. San Francisco. Association for Consumer Research

Broderick, A.J. ( 1999 ): Role theory and the management of service encounters. The Service Industries Journal, 19 (2): p. 117-131.

Cho, H. - Fiorito, S.S. (2010): Self-Service Technology in Retailing. The Case of Retail Kiosks Symphonya. Emerging Issues in Management, 1: p. 43-56.

Cunningham, L.F. - Young, C.E. - Gerlach, J. (2009): A comparison of consumer views of traditional services and self-service technologies. Journal of Services Marketing, Vol. 23 (1): p. 11-23.

Curran, J.M. - Meuter, M.L. (2005): Self-Service Technology Adoption: Comparing Three Technologies. Journal of Services Marketing, 19 (2): p. 103-113.

Curran, J.M. - Meuter, M.L. (2007): Encouraging existing customers to use self-service technologies: put a little fun in their lives. Journal of Marketing Theory and Practice, Vol. 15 (4): p. 283-298.

Dabholkar, P.A. (1996): Consumer evaluations of new technology-based self-service options: An investigation of alternative models of service quality. Intern. Journal of Research in Marketing, 13: p. 29-51.

Dabholkar, P.A. - Bagozzi, P.R. (2002): An attitutional model of technology-based self-service: Moderating effects of consumer traits and situational factors. Journal of Academy of Marketing Science, (30): p. 184-201.

Davis, F.D. (1989): Perceived usefulness, perceived ease of use and user acceptance of information technology. MIS Quarterly, Vol. 13 (3): p. 318-339.

Davis, L.D. - Bagozzi, R.P. - Warshaw, P.R. (1989): User acceptance of computer technology: A comparison of two theoretical models. Management Science, 35 (8): p. 982-1003.

Drótos Gy. - Móricz P. (2012): A vállalati informatika szerepe a versenyképesség alakításában a pénzügyi és gazdasági válság időszakában. Vezetéstudomány, 43 (1): p. 80-89.

Drótos Gy. - Szabó Z. (2001): Vállalati informatika Magyarországon az ezredfordulón - Mítosz és valóság. Vezetéstudomány, 32 (2): p. 17-24.

Duma L. - Erdôs Sz. (2008): A jövő intelligens technológiai és menedzsmentkérdései. Vezetéstudomány, 39 (12): p. 60-68.

Edvardsson, B. - Roos, P. (2001): Critical Incident Techniques Towards A Framework For Analysing The Criticality Of Critical Incidents. International Journal of Service Industry Management, Vol. 12 (3): p. 251-268.

Elliott, K.M. - Hall, M.C. - Meng, J.G. (2013): Consumers' intention to use self-scanning technology: the role of technology readiness and perceptions toward selfservice technology. Academy of Marketing Studies Journal, Volume 17 (1): p. 129-143.

Erasmus, A.E. - Boshoff, E. - Rousseau, G.G. (2002): The potential of using script theory in consumer behaviour research. Journal of Family Ecology and Consumer Sciences, Vol. 30: p. 1-9.

Gelderman, C.J. - Ghijsen, P.W.Th. - Diemen, R.V. (2011): Choosing self-service technologies orinter personal services - The impact of situational factors and technology-related attitude. Journal of Retailing and Consumer Services, 18: p. 414-421.

Glushko, R.J. - Nomorosa, K.J. (2012): Substituting Information for Interaction: A Framework for Personalization in Service Encounters and Service Systems. Journal of Service Research, 16 (1): p. 21-38.

Grove, S.J. - Carlson, L. - Dorsch, M.J. (2002): Addressing services' intangibility through integrated marketing communication: an exploratory study. The Journal of Services Marketing, 16 (5): p. 393-411.

Grove, S.J. - Fisk, R.P. (1983): The dramaturgy of services exchange: An analytical framework for services marketing. in: L. Leonard, G. Berry, L. Shostack and G.D. Upah (eds.): Emerging Perspectives on Services Marketing. Chicago, IL: American Marketing Association: p. 45-49.

Grove, S.J. - Fisk, R.P. (1992): The service experience as theater. Advances in Consumer Research, 19: p. 455461.

Hilton, T. - Hughes, T. - Little, E. - Marandi, E. (2013): Adopting self-service technology to do more with less. Journal of Services Marketing, 27/1: p. 3-12.

Hsieh, C. (2005): Implementing Self-Service Technology To Gain Competitive Advantages. Communications of IIMA, Vol. 5: p. 77-83.

Hsu, T.-H. - Chu-Yin, C. (2011): Script Comparisons during Service Encounters in Fast-Food Chains. Tourism and Hospitality Research, Vol. 11 (1): p. 19-31.

Kenesei Zs. - Kolos K. (2014): Szolgáltatásmarketing és menedzsment. Budapest: Alinea Kiadó

Keszey T. (2007): Az informatika helyzete és lehetôségei a magyar nagyvállalatok marketing- és értékesítési tevékenységének támogatásában. Vezetéstudomány, 38: p. $27-46$.

Kolos K. (2008): Az ötvenen túliak mint növekvô jelentőségú célcsoport. Vezetéstudomány, 9: p. 19-30.

Leonardi, P.M. (2013): Theoretical foundations for the study of sociomateriality. Information and Organization, 23: p. 59-76.

Lovelock, C.H. - Gummesson, E. (2004): Whither Services Marketing?: In Search of a New Paradigm and Fresh Perspectives. Journal of Service Research, 7 (1): p. 20-41.

Lin, J.S.C. - Chang, H.C. (2012): The role of technology readiness in self-service technology acceptance. Managing Service Quality, Vol. 21 (4): p. 424-444.

Meuter, M.L. - Ostrom, A.L. - Bitner, M.J. - Roundtree, R. (2003): The influence of technology anxiety on consumer use and experiences with self-service technologies. Journal of Business Research, Vol. 56: p. 899-906.

Meuter, M. - Ostrom, A. - Roundtree, R.I. - Bitner, M.J. (2005): Choosing Among Alternative Service Delivery 
Modes: An Investigation of Customer Trial of SelfService Technologies. Journal of Marketing, Vol. 69: p. 61-83.

Meuter, M.L. - Ostrom, A.L. - Roundtree, R.I. - Bitner, M.J. (2000): Self-service technologies: Understanding customer satisfaction with technology based service encounters. Journal of Marketing, Vol. 64 (3): p. 50-64.

Orlikowski, W.J. - Scott, S.V. (2008): Sociomateriality: Challenging the separation of technology, work and organization. The Academy of Management Annals, 2 (1): p. 433-474.

Parasuraman, A. (2000): Technology readiness index (TRI): A multiple-item scale to measure readiness to embrace new technology. Journal of Service Research, 2 (4): p. 307-320.

Prahalad, C.K. - Ramaswamy, V. (2000): Co-Opting Customer Competence. Harvard Business Review, 78 (1): p. 79-87.

Rogers, E.M. (1985): Diffusion of Innovations. 3rd ed. New York: The Free Press

Salomann, H. - Dous, M. - Kolbe, L. - Brenner, W. (2007): Self-service revisited: How to balance high-tech and high-touch in customer relationships. European Management Journal, Vol. 25 (4): p. 310-319.

Salomann, H. - Kolbe, L. - Brenner, W. (2006): Self-Services In Customer Relationships: Balancing High-Tech And High Touch Today And Tomorrow. eService Journal, Vol. 4 (2): p. 65-87.

Spotts, H.E. - Schewe, C.D. (1989): Communicating with the elderly consumer: the growing health care challenge. Journal of Health Care Marketing, 9 (3): p. 36-44.
Vargo, S.L. - Lusch, R.F. (2004): The Four Services Marketing Myths: Remnants from a Manufacturing Model. Journal of Service Research, 6 (4): p. 324-335.

Veres Z. (2009): A szolgáltatásmarketing alapkönyve. Budapest: Akadémia Kiadó

Victorino, L. - Verma, R. - Bonnet, B.L. - Wardell, G. (2012): Can Customers Detect Script Usage in Service Encounters? An Experimental Video Analysis. Journal of Service Research, 15 (4): p. 390-400.

Wunderlich, P. - Kranz, J. - Totzek, D. - Veit, D. - Picot, A. (2013): The Impact of Endogenous Motivations on Adoption of IT-Enabled Services: The Case of Transformative Services in the Energy Sector. Journal of Service Research, 16 (3): p. 356-371.

Wang, C. - Harris, J. - Patterson, P.G. (2012): Customer Choice of Self-Service Technology: The Roles of Situational Influences and Past Experience. Journal of Service Management, 23 (1): p. 54-78.

Wünderlich, N.V. - Wangenheim, F. - Bitner, M.J. (1993): High Tech and High Touch: A Framework for Understanding User Attitudes and Behaviors Related to Smart Interactive Services. Journal of Service Research, 16 (1): p. 3-20.

Zeithaml, V.A. - Gilly, M.C. (1987): Characteristics affecting the acceptance of retailing technologies: a comparison of elderly and non-elderly consumers. Journal of Retail Banking, Vol. 63 (1): p. 49- 68.

Zhu, Z. - Nakata, C. - Sivakumar, K. - Grewal, D. (2007): Self-Service Technology Effectiveness: The Role of Design Features and Individual Traits. Journal of the Academy of Marketing Science, 35 (4): p. 492-506. 